\title{
Imperial persuaders
}

Images of Africa and Asia in British advertising

A N A N D I R A M A M UR T HY

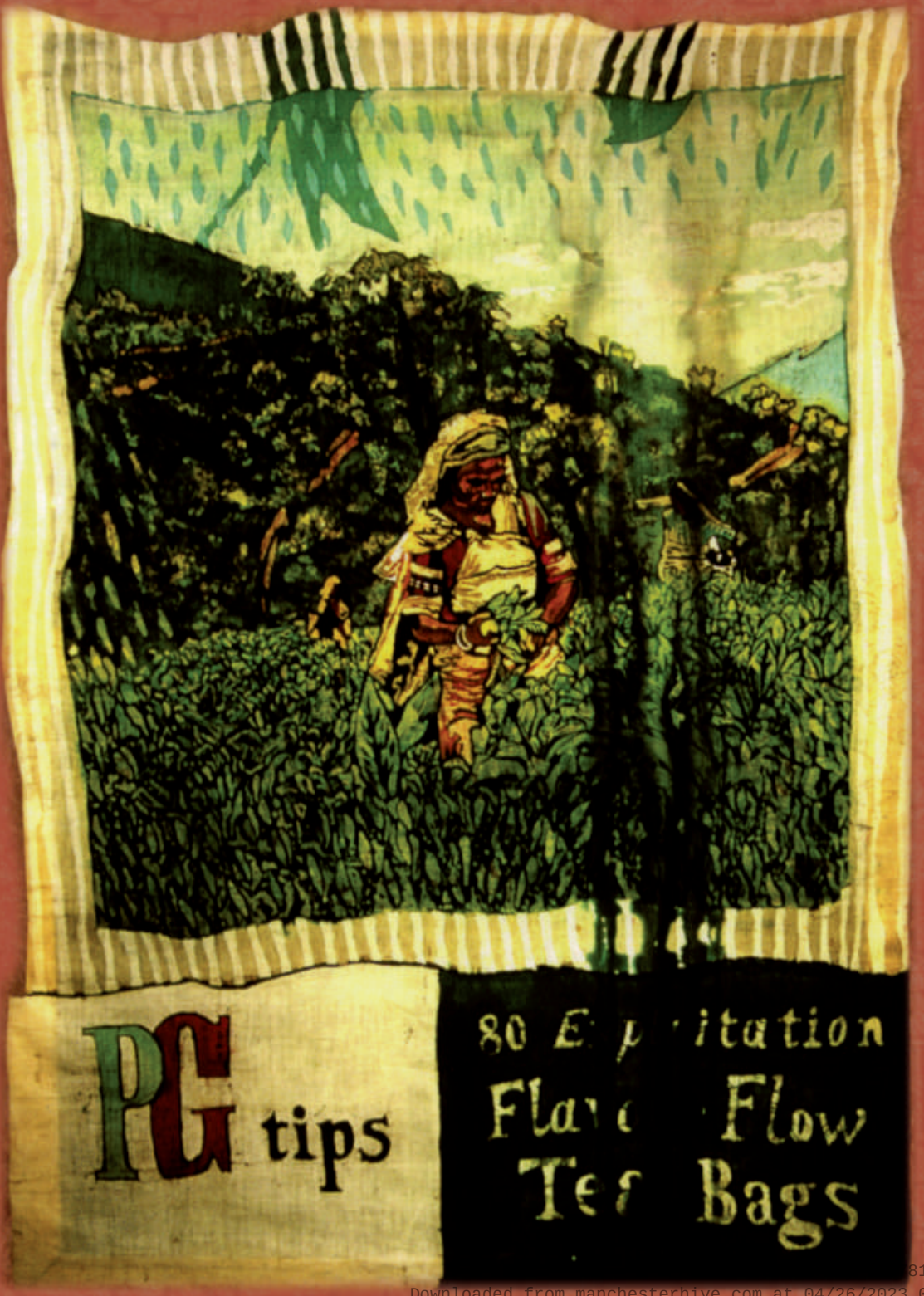




\section{\begin{tabular}{l} 
- STUDIES IN- \\
IMPERIALISM \\
\hline
\end{tabular}}

general editor John M. MacKenzie

When the 'Studies in Imperialism' series was founded by Professor John M. MacKenzie more than thirty years ago, emphasis was laid upon the conviction that 'imperialism as a cultural phenomenon had as significant an effect on the dominant as on the subordinate societies'. With well over a hundred titles now published, this remains the prime concern of the series. Cross-disciplinary work has indeed appeared covering the full spectrum of cultural phenomena, as well as examining aspects of gender and sex, frontiers and law, science and the environment, language and literature, migration and patriotic societies, and much else. Moreover, the series has always wished to present comparative work on European and American imperialism, and particularly welcomes the submission of books in these areas. The fascination with imperialism, in all its aspects, shows no sign of abating, and this series will continue to lead the way in encouraging the widest possible range of studies in the field. Studies in Imperialism is fully organic in its development, always seeking to be at the cutting edge, responding to the latest interests of scholars and the needs of this everexpanding area of scholarship.

\section{Imperial persuaders}


Anandi Ramamurthy - 9781526118578 Downloaded from manchesterhive.com at $04 / 26 / 2023$ 02:14: 03 PM via free access 


\section{Imperial persuaders}

IMAGES OF AFRICA AND ASIA IN BRITISH ADVERTISING

Anandi Ramamurthy

MANCHESTER UNIVERSITY PRESS

Manchester 
Copyright (C) Anandi Ramamurthy 2003

The right of Anandi Ramamurthy to be identified as the author of this work has been asserted by her in accordance with the Copyright, Designs and Patents Act 1988.

Published by Manchester University Press

Altrincham Street, Manchester M1 7JA, UK

www.manchesteruniversitypress.co.uk

British Library Cataloguing-in-Publication Data is available

Library of Congress Cataloging-in-Publication Data is available

ISBN 9780719063794 paperback

First published by Manchester University Press in 2003

The publisher has no responsibility for the persistence or accuracy of URLs for any external or third-party internet websites referred to in this book, and does not guarantee that any content on such websites is, or will remain, accurate or appropriate. 